\title{
Efektivitas kapasitas kerja dalam pengelolaan lanskap area permainan Emeralda Golf Club, Tapos, Depok
}

\author{
Muplihudin ${ }^{\star}$, Priambudi Trie Putra ${ }^{1}$, Ray March Syahadat ${ }^{1}$, Daisy Radnawati ${ }^{1}$
}

1. Program Studi Arsitektur Lanskap, Fakultas Teknik Sipil dan Perencanaan, Institut Sains dan Teknologi Nasional, Jakarta, Indonesia.

*E-mail: muplihudin28@gmail.com

\begin{abstract}
Working Capacity Effectivity in Landscape Management of Game Area at Emeralda Golf Club, Tapos, Depok. Golf course landscape are one of the green open space form that created for recreational sports. Inside the golf course is dominated by grass. One of the golf courses in Depok is Emeralda Golf Club. So far at Emeralda Golf Club, there has never been a study on working capacity. As a result, there has no definite reports on management and number of workers. The aims of this study was to calculate the effectiveness of working capacity in the Emeralda Golf Club. Study was limited at the game area at Emeralda Golf Course. The stages were preparation, data collection, analysis, and synthesis. Data collected by observation, interviews, and literature studies. The data analyzed both qualitatively and quantitatively. The results obtained by the number of workers are still considered not enough to meet the standards in managing the golf course.
\end{abstract}

Keywords: Golf course landscape, golf course management, green open space, landscape management, recreational sport.

\section{Pendahuluan}

Seiring dengan padatnya aktivitas dan kegiatan manusia sehari-hari yang membuat pikiran penat ataupun badan lelah menimbulkan adanya pemikiran bagi beberapa orang untuk melakukan kegiatan refreshing ataupun olahraga sejenak, dengan tujuan untuk mengembalikan kebugaran dan menghilangkan rasa penat di dalam pikirannya. Salah satu kegiatan yang bisa memadukan antara refreshing dan olahraga yaitu dengan bermain golf. Golf merupakan salah satu olahraga yang bersifat rekreatif, karena dalam olahraga golf pemain dapat merasakan ketenangan dan keindahan alam dengan berbagai fasilitas yang tersedia di dalamnya (Beard, 1982). Pada pembangunan real estat, fasilitas lapangan golf memiliki nilai investasi yang menjanjikan dari pada tanpa fasilitas lapangan golf (Anastasia et al, 2001). Tak heran keberadaan lapangan golf terus berkembang di Indonesia di samping pembangunan kawasan wisata, perkantoran, maupun perumahan (Samadikun, 2007).

Padang Golf Emeralda Golf Club (EGC) merupakan salah satu lapangan golf dengan $3 \times 9$ holes atau merupakan golf course dengan 27 holes yang tergolong padang golf papan atas karena kondisinya terawat dengan baik mulai dari tee box, fairway, hazard, rough, dan green. Dalam pengelolaan lanskap, tentunya ada beberapa hal yang perlu diperhatikan untuk mencapai tujuannya seperti tenaga kerja, peralatan, organisasi, dan anggaran (Arifin dan Arifin, 2005). Tujuan pengelolaan lanskap di lapangan golf tentu saja untuk menjaga agar kondisi lapangan golf tetap baik dan memuaskan bagi pengguna (Petrick et al., 1999).

Salah satu faktor yang memengaruhi ketercapaian tujuan pengelolaan lanskap lapangan golf yaitu efektivitas kapasitas kerja (Dlukha et al., 2017). Sebagai salah satu komponen penting dalam keberhasilan pengelolaan, tenaga kerja tidak hanya harus terampil tetapi juga harus cukup sesuai dengan kapasitasnya (Putra et al., 2017). Namun, kajian mengenai lapangan golf lebih banyak kepada elemen lapangan golf seperti jenis rumput maupun pemupukan terhadap lapangan golf (Nasrullah dan Tunggalini, 2000; Guntoro et al., 2007; Guntoro et al., 2006; Hardiman dan Wicaksono, 2018). Padahal manajemen lapangan golf juga merupakan seuatu hal yang penting untuk menjaga keberlanjutan lapangan golf itu sendiri (Dewi, 2014). Penelitian yang dilakukan Utami (2013) menyatakan bahwa efisiensi dapat dilakukan dengan cara pengendalian persediaan bahan habis pakai. 
Pengelolaan lapangan golf yang baik tidak hanya melihat dari efisiensi tetapi juga efektifitas seluruh komponen pengelolaan. Sejauh ini di Padang Golf EGC, belum pernah ada kajian mengenai kapasitas kerja. Akibatnya, pengelola belum mengetahui apakah selama ini proses pengelolaan area permainan berlangsung efektif dan efisien? Apakah jumlah tenaga kerja yang ada sudah cukup dalam melaksanakan pengelolaan area permaianan? Berakar dari permasalahan tersebut, maka studi ini dilakukan. Adapun tujuannya yaitu menghitung efektivitas kapasitas kerja di Padang Golf EGC, sebagai salah satu faktor keberhasilan pengelolaan lanskap padang golf.

\section{Metode}

Studi dilaksanakan di Padang Golf EGC, Jalan Cimanggis Boulevard, Kecamatan Tapos, Depok, Jawa Barat (Gambar 1). pada bagian lanskap area permainan golf/turfgrass. Pelaksanaan studi dilakukan sejak Oktober 2016 hingga Januari 2017. Studi dibatasi pada area permainan di Padang Golf ECC. Tahapannya yaitu persiapan, pengumpulan data, analisis, dan sintesis. Teknik pengumpulan data dilakukan dengan cara observasi, wawancara, dan studi literatur. Data yang didapatkan dari hasil observasi yaitu organiasi kerja, suberdaya manusia, elemen lanskap, perhitungan jumlah pekerja, volume pekerjaan, kapasitas pekerjaan, dan lama pelaksanaan. Data-data tersebut berguna untuk menilai keberhasilan pengelolaan lapangan golf. Kegiatan wawancara dilakukan kepada pihak pekerja serta pengelola yang terkait secara langsung dalam manajemen pengelolaan lanskap area permainan Padang Golf EGC. Sedangkan studi literatur digunakan untuk memperoleh teori, standar, dan ketetapan, serta hasil-hasil penelitian pengelolaan padang golf. Data yang dikumpulkan kemudian dianalisis baik secara kualitatif maupun kuantitatif. Eektivitas kapasitas kerja dianalisis dengan menggunakan formula dari Febriani (1998). Pendekatan ini juga pernah dilakukan oleh Dlukha et al. (2017), dalam menghitung efektivitas kapasitas kerja pada area hazard lapangan golf. Adapun formula yang digunakan yaitu sebagai berikut:

$$
\mathrm{TJK}=(\mathrm{VK} / \mathrm{KK}) / \mathrm{P}
$$

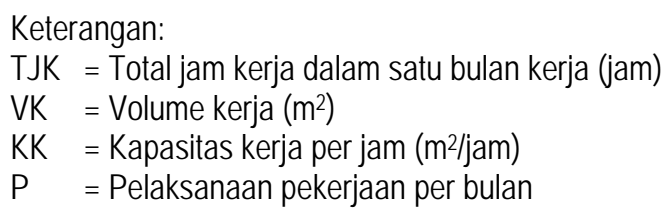

Untuk mencari rasio perbandingan pekerjaan dilakukan dengan cara, membagi luas area permainan yang akan dipelihara dengan standar tenaga kerja yang telah ditemukan dari hasil perhitungan total jam kerja. Perbandingan rasio yang ideal adalah $1: 0,1$ sampai $1: 0,3$ yang artinya setiap satu orang pekerja memiliki area yang harus dipelihara seluas 0,1 sampai dengan 0,3 ha.

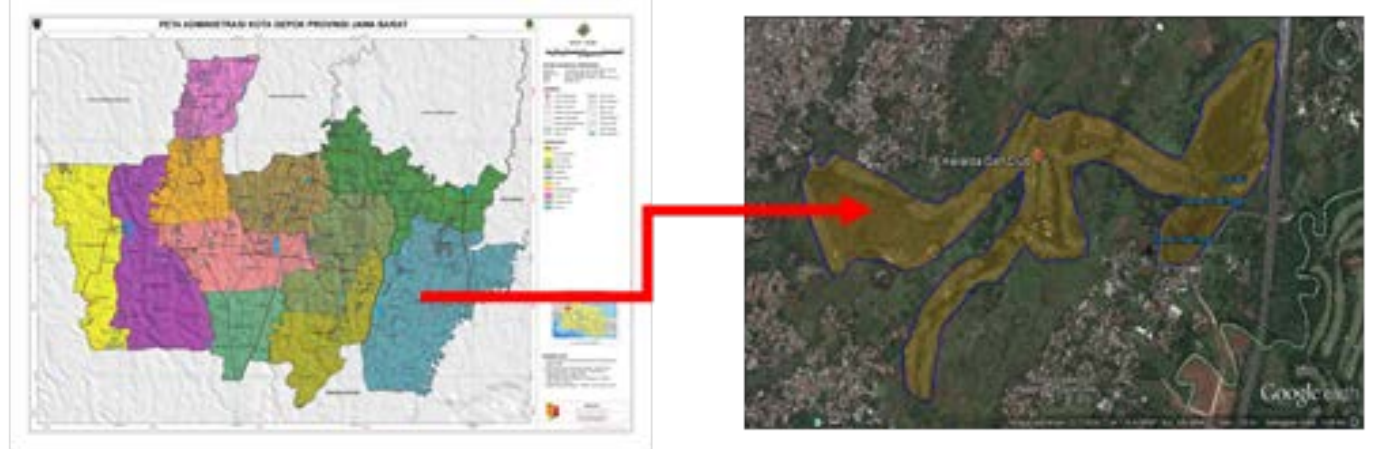

Gambar 1. Lokasi Studi

\section{Hasil dan Pembahasan}

\subsection{Kondisi umum}

Padang golf ini dimiliki oleh PT Karabha Digdaya yang dibangun pada tahun 1992 dan selesai pada tahun 1994 dengan total 27 lapangan atau holes. Konsep padang golf yang digunakan ialah dengan membagi 27 holes tersebut menjadi tiga course. Course yang pertama diberi nama River Course karena pada bagian lapangan ini terdapat Sungai Sunter yang melintang di beberapa bagian lapangan. Course yang kedua diberi nama Lake Course yang memanfaatkan danau-danau yang ada dengan penambahan beberapa 
danau buatan sebagai fungsi rintangan, estetika, dan penampungan air. Course yang ketiga diberi nama Plantation Course dengan konsep penggunaan tanaman hijau tropis (Gambar 2).

Ketiga course ini dirancang oleh dua pemain sekaligus perancang lapangan golf ternama asal Amerika Serikat yaitu Arnold Palmer dan Jack Nicklaus. Arnold Palmer sebagai perancang lapangan di bagian River Course dan Lake Course sedangkan Jack Nicklaus sebagai perancang lapangan di bagian Plantation Course. Sebelumnya lokasi tapak Padang Golf EGC merupakan area hutan, persawahan, dan perkebunan karet milik pribadi. Kemudian di area ini dibangun sebuah lapangan golf dengan luas keseluruhan area \pm 900 ha dengan luas area permainan $\pm 106,7$ ha. Pada tahun 1998, kepemilikannya berpindah kepada Departemen Keuangan Kota Depok hingga sampai saat ini.

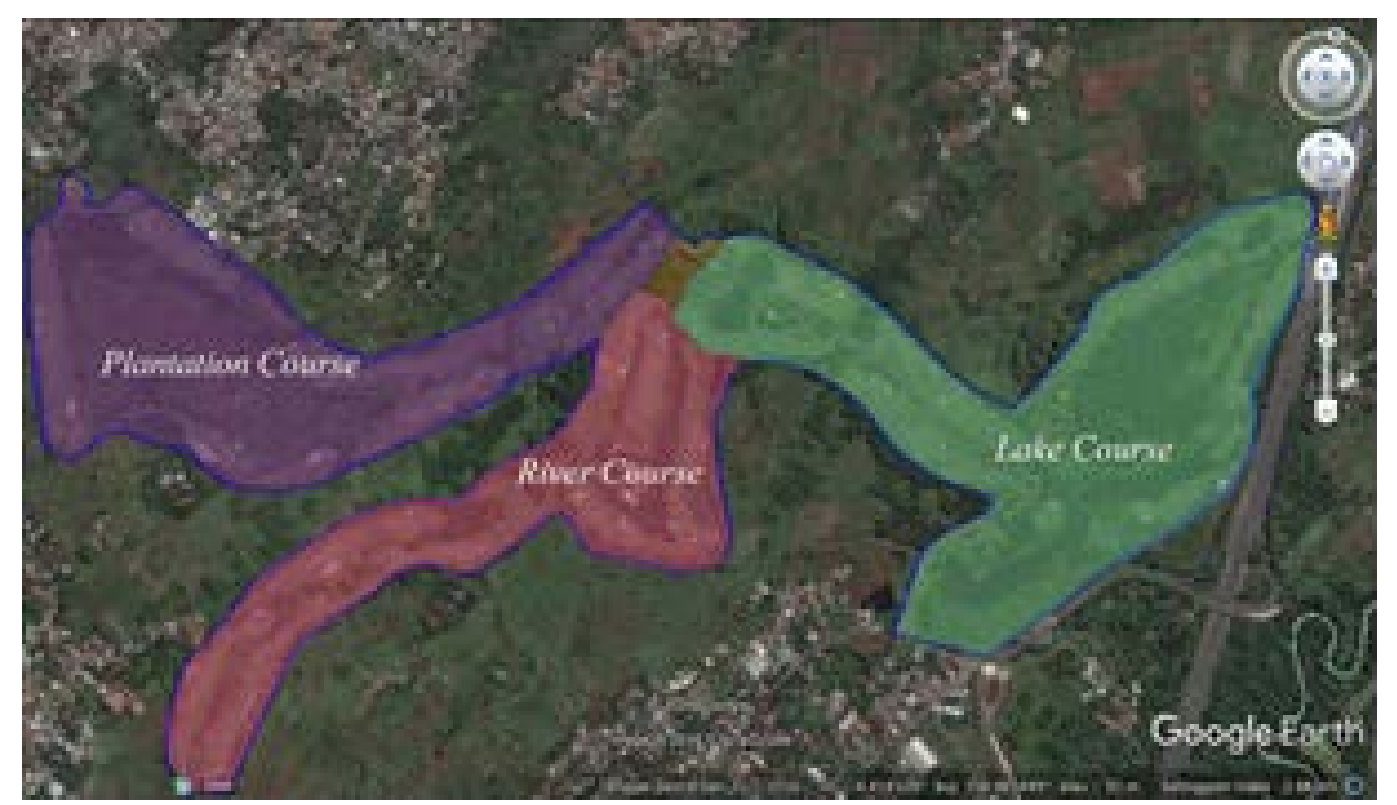

Gambar 2. Pembagian Course di Padang Golf EGC

\subsection{Organisasi kerja}

Dalam struktur organisasi Departemen Maintenance di Padang Golf EGC terdapat 139 orang pengelola terdiri dari superintendent, administrasi, turfgrass, mekanik, golf cart, store keeper, irigasi, carpentry, dan landscape. Tenaga kerja yang bekerja langsung di lapangan yaitu berjumlah 116 orang kecuali mekanik, golf cart, office boy, administrasi, driver, formen, supervisor dan superintendent (Gambar 3). Program kerja pengelolaan meliputi jenis kegiatan, frekuensi pekerjaan, alat yang digunakan, dan jumlah pekerja untuk pelaksanaan kegiatan pengelolan. Pembuatan program pengelolaan di Padang Golf EGC dilakukan setiap satu tahun oleh superintendent melalui meeting dengan seluruh supervisor divisi bagian maintenance. Program pengelolaan terdiri dari dua program yaitu pengelolaan rutin dan pengelolaan nonrutin/insidental. Pengelolaan rutin dilaksanakan secara berkala yaitu per hari, per minggu, dan per bulan sedangkan program pengelolaan nonrutin hanya dilakukan pada waktu tertentu sesuai dengan kondisi lapangan.

\subsection{Sumber daya manusia}

Jumlah keseluruhan sumber daya manusia atau tenaga kerja yang ada di Padang Golf EGC pada divisi maintenance yaitu berjumlah 139 orang yang terdiri dari superintendent, supervisor, formen, administrasi, operator, staf permanen, dan kontrak. Tenaga kerja permanen merupakan tenaga kerja yang sudah lama bekerja atau bekerja mulai dari pertama pembangunan Padang Golf EGC. Sedangkan tenaga kerja kontrak merupakan tenaga kerja yang sudah termasuk dalam ketentuan baru yaitu tenaga kerja hanya diberi kesempatan waktu untuk bekerja selama satu tahun setelah habis masa kerjanya kemudian pekerja diistirahatkan dan diganti dengan pekerja yang baru. Hal ini dilakukan dengan tujuan untuk memberikan kesempatan kepada warga lain yang ingin bekerja dengan cara bergiliran selama satu tahun, mengingat banyaknya warga setempat atau warga lain yang ingin mendapat kesempatan untuk bisa bekerja di Padang Golf EGC. 


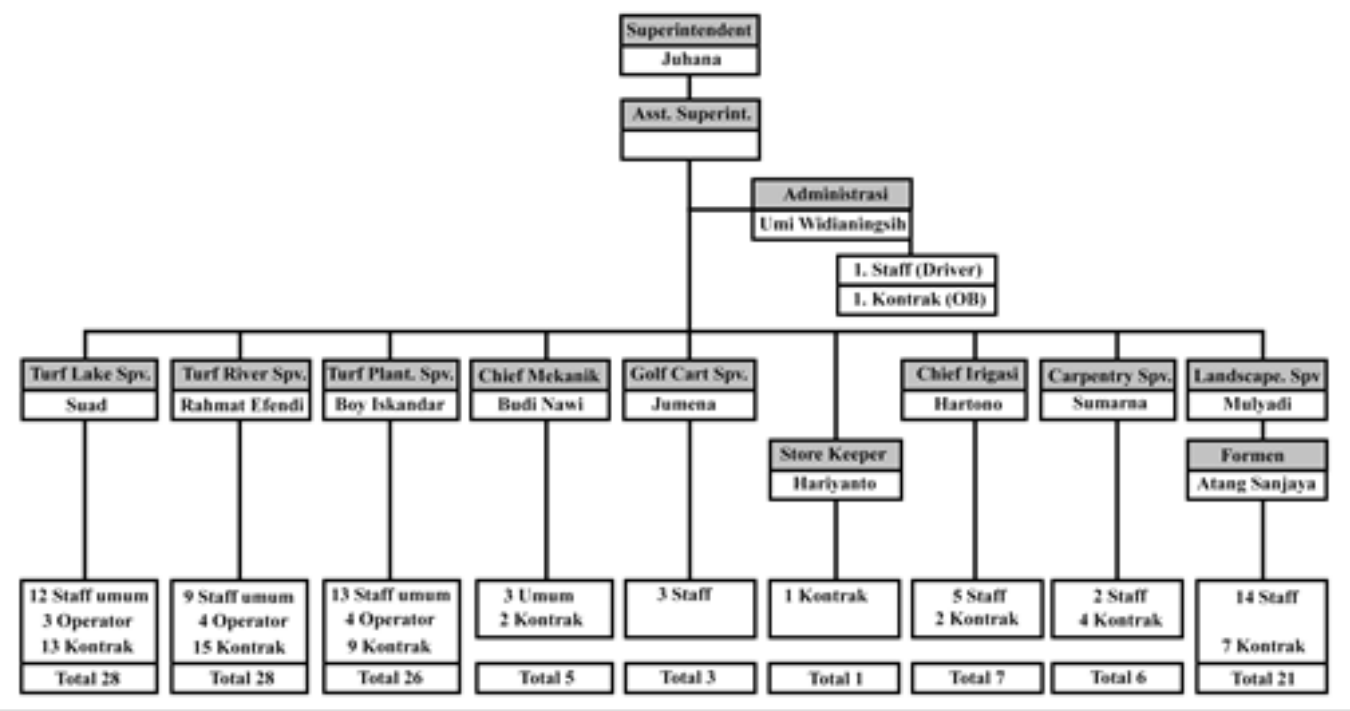

Gambar 3. Struktur Organisasi Departemen Maintenance

Tenaga kerja yang digunakan merupakan tenaga kerja dari lingkungan setempat atau warga sekitar yang tidak jauh dari lokasi Padang Golf EGC. Tenaga kerja yang bekerja langsung di lapangan kecuali mekanik, golf cart, office boy, driver, formen, supervisor, dan superintendent berjumlah 116 orang (Gambar 4). Sebanyak 116 tenaga kerja tersebut mengerjakan pengelolaan di green, tee box, fairway, rough, semi rough, apron, dan bunker (Gambar 5). Tenaga kerja melakukan pekerjaannya selama enam hari dalam seminggu. Pada hari Senin sampai dengan hari Kamis pekerja bekerja selama 7,5 jam, pada hari Jumat bekerja selam 6 jam, dan pada hari Sabtu bekerja selama 4 jam. Kegiatan pekerjaan dimulai 05:30 WIB.

\subsection{Elemen lanskap Padang Golf EGC}

Elemen lanskap merupakan fasilitas yang digunakan dalam desain lanskap sebagai penunjang dalam kebutuhan untuk tercapainya suatu perencanaan yang diinginkan. Elemen lanskap yang ada di Padang Golf EGC dibagi menjadi beberapa bagian yaitu terdiri dari elemen soft material, elemen hard material, dan hazard. Elemen soft material terdiri dari tee box, fairway, green, rough, dan vegetasi. Elemen hard material terdiri dari cartpath, shelter, jembatan, tempat sampah, penerangan, mainhole, patok-patok, distance marker, satellite control, sprinkler, dan penangkal petir. Hazard terdiri dari danau, sungai, dan juga bunker.

\subsection{Efektivitas kapasitas kerja}

Berdasarkan hasil pengamatan di Padang Golf EGC diperoleh luas area permainan sebesar 106,7 ha dengan jumlah tenaga kerja yang bekerja langsung di lapangan yaitu berjumlah 116 orang yang terdiri dari 11 operator, 55 staf permanen, dan 50 kontrak. Rasio tenaga kerja yang diterapkan di Padang Golf EGC adalah 0,9 ha yang artinya satu orang pekerja memiliki area yang harus dipelihara seluas 0,9 ha. Hal ini sangat jauh dari perbandingan ideal yang berkisar antara $1: 0,1$ sampai $1: 0,3$. Fenomena ini dibuktikan dengan adanya pemberlakuan lembur bagi para pekerja.

Besarnya kapasitas kerja dan kebutuhan waktu pelaksanaan pemeliharaan lanskap area permainan selama satu bulan ditampilkan pada Tabel 1. Dari hasil perhitungan setiap bulannya dibutuhkan 165.814 jam kerja. Tenaga kerja melakukan pekerjaannya enam hari dalam satu minggu. Pada hari Senin sampai dengan hari Kamis bekerja selama 7,5 jam. Hari Jumat pekerja bekerja selama 6 jam. Kemudian, pada hari Sabtu bekerja selama 4 jam. Dengan demikian dalam satu bulannya satu orang akan melakukan pekerjaan selama 187,5 jam. Dengan diketahuinya jam kerja per orang dan rata-rata jam kerja untuk semua pekerjaan dalam waktu satu bulan maka untuk luasan area permainan yang dipelihara membutuhkan sekurang- kurangnya 884 pekerja. Rasio yang diperoleh dengan 884 pekerja menjadi $1: 0,1$ yang artinya setiap satu orang pekerja memiliki area yang harus dipelihara seluas 0,1 ha agar proses pengelolaan area permainan efektif dan efisien. Namun jumlah tenaga kerja dapat diturunkan menjadi 305 dan rasio yang didapatkan menjadi 0,3 ha. Artinya jika mengambil rasio $1: 0,3$ setiap satu orang pekerja akan memiliki area yang harus dipelihara seluas $0,3 \mathrm{ha}$. 

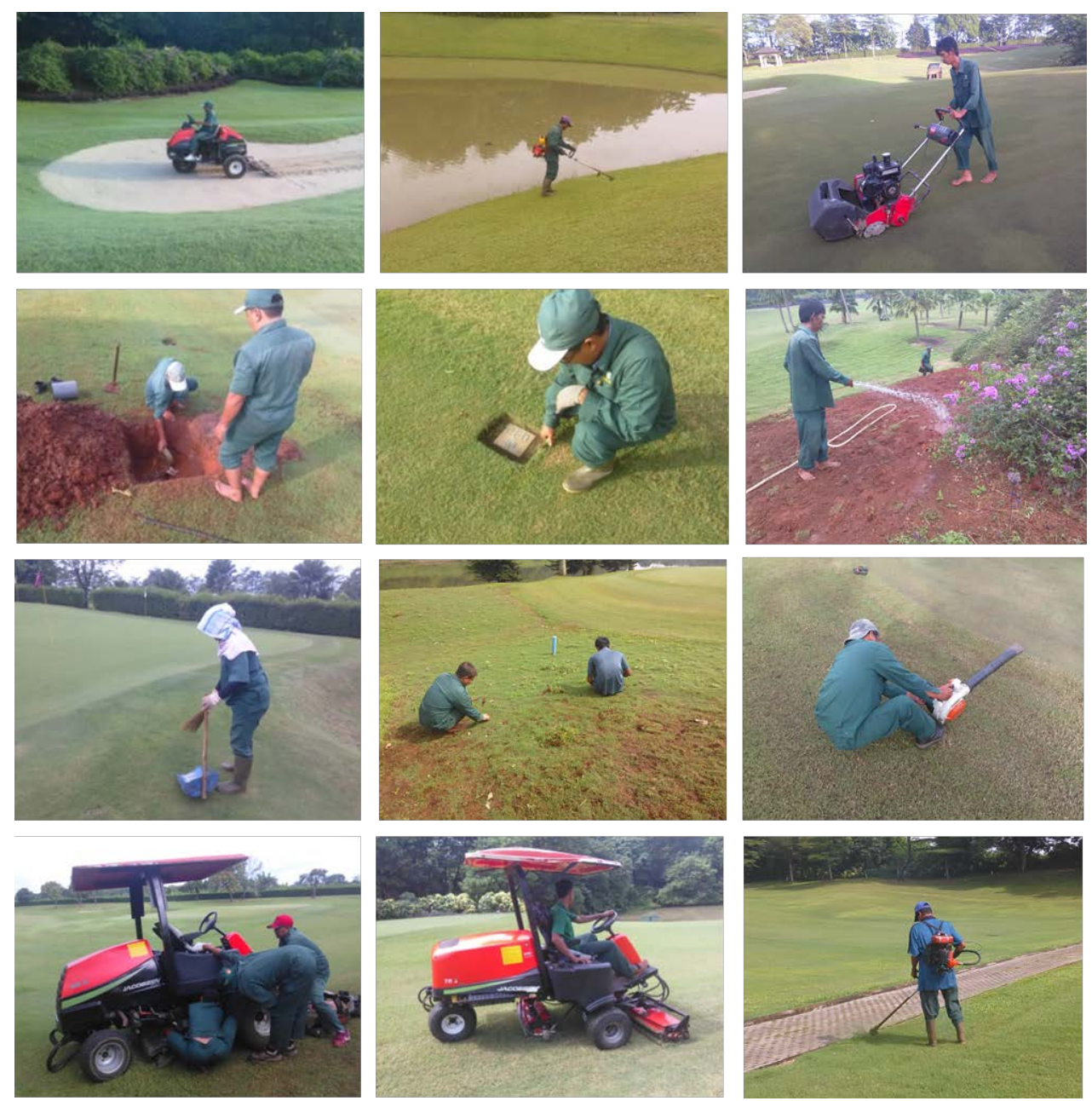

Gambar 4. Pekerjaan yang Dilakukan Tenaga Kerja
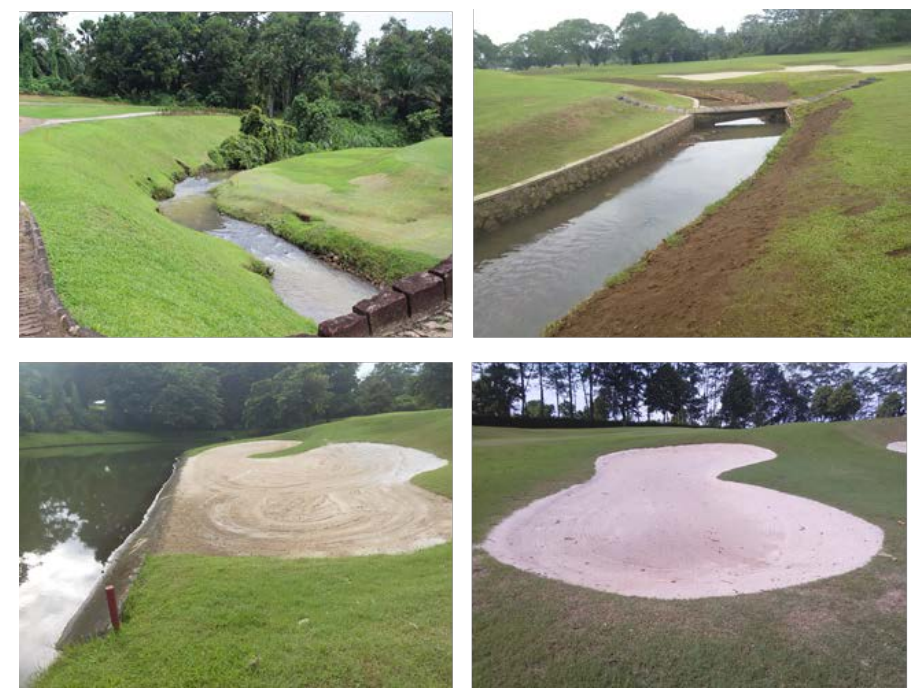

Gambar 5. Area Pengelelolaan 
Tabel 1. Kapasitas kerja dan kebutuhan waktu pelaksanaan pemeliharaan selama satu bulan

\begin{tabular}{|c|c|c|c|c|c|}
\hline No & Uraian pekerjaan & $\begin{array}{l}\text { Volume } \\
\text { pekerjaan } \\
\left(\mathrm{m}^{2}\right)\end{array}$ & $\begin{array}{l}\text { Kapasitas pekerjaan } \\
/ \text { jam }\left(\mathrm{m}^{2}\right)\end{array}$ & $\begin{array}{l}\text { Pelaksanaan / } \\
\text { bulan (kali) }\end{array}$ & $\begin{array}{l}\text { Rata-rata } \\
\text { pelaksanaan / } \\
\text { bulan (jam) }\end{array}$ \\
\hline \multirow[t]{5}{*}{1} & Pemeliharaan green & & & & \\
\hline & Pemangkasan & 18.000 & 500 & 30 & 1080 \\
\hline & Pemupukan & 18.000 & 200 & 2 & 180 \\
\hline & penyiraman & 18.000 & 500 & 30 & 1080 \\
\hline & $\begin{array}{l}\text { Pembersihan dan } \\
\text { penyiangan }\end{array}$ & 18.000 & 400 & 30 & 1350 \\
\hline \multirow[t]{5}{*}{2} & Pemeliharaan Tee box & & & & \\
\hline & Pemangkasan & 22.576 & 500 & 8 & 361 \\
\hline & Pemupukan & 22.576 & 200 & 0.3 & 34 \\
\hline & penyiraman & 22.576 & 500 & 30 & 1355 \\
\hline & $\begin{array}{l}\text { Pembersihan dan } \\
\text { penyiangan } \\
\text { Pemeliharaan Fairway }\end{array}$ & 22.576 & 400 & 30 & 1693 \\
\hline \multirow{4}{*}{3} & Pemangkasan & 229.000 & 500 & 16 & 7328 \\
\hline & Pemupukan & 229.000 & 200 & 0.3 & 344 \\
\hline & penyiraman & 229.000 & 500 & 30 & 13740 \\
\hline & $\begin{array}{l}\text { Pembersihan dan } \\
\text { penyiangan } \\
\text { Pemeliharaan Rough }\end{array}$ & 229.000 & 400 & 30 & 17175 \\
\hline \multirow{3}{*}{4} & Pemangkasan & 721.000 & 500 & 8 & 11536 \\
\hline & penyiraman & 721.000 & 500 & 30 & 43260 \\
\hline & $\begin{array}{l}\text { Pembersihan dan } \\
\text { penyiangan } \\
\text { Pemeliharaan Apron }\end{array}$ & 721.000 & 400 & 30 & 54075 \\
\hline \multirow{3}{*}{5} & Pemangkasan & 38.880 & 500 & 12 & 933 \\
\hline & penyiraman & 38.880 & 500 & 30 & 2592 \\
\hline & $\begin{array}{l}\text { Pembersihan dan } \\
\text { penyiangan } \\
\text { Semi Rough }\end{array}$ & 38.880 & 400 & 30 & 2916 \\
\hline \multirow{3}{*}{6} & Pemangkasan & 22.500 & 500 & 8 & 360 \\
\hline & penyiraman & 22.500 & 500 & 30 & 1350 \\
\hline & $\begin{array}{l}\text { Pembersihan dan } \\
\text { penyiangan } \\
\text { Bunker }\end{array}$ & 22.500 & 400 & 30 & 1688 \\
\hline \multirow{3}{*}{7} & Pemangkasan slope & 15.202 & 250 & 4 & 244 \\
\hline & Pembersihan & 15.202 & 400 & 30 & 1140 \\
\hline & \multicolumn{4}{|c|}{ Total jam kerja dalam waktu satu bulan } & 165814 \\
\hline
\end{tabular}

Dari hasil yang temukan, terlihat bahwa efektivitas tenaga kerja pada pengelolaan lapangan golf, tidak sama satu sama lain. Hal ini dapat dilihat dari penelitian sejenis yang pernah dilakukan oleh Dlukha et al. (2017) yang menunjukkan perbedaan jumlah tenaga kerja. Untuk itu setiap lapangan golf perlu melakukan perhitungan efektivitas tenaga kerja. Perbedaan-perbedaan tersebut dipengaruhi oleh beberapa hal seperti keahlian dan keterampilan tenaga kerja, peralatan, luas area, desain, elemen penyusun, dan organisasi kerja. 


\section{Simpulan}

Secara umum kegiatan pengelolaan lanskap di area permainan Padang Golf EGC sudah cukup baik dilihat dari organisasi dan program kerja. Berdasarkan hasil analisis yang dilakukan, jumlah tenaga kerja masih dianggap belum cukup untuk memenuhi standar dalam pengelolaan area permainan. Padang Golf EGC memerlukan sekurang-kurangnya 305 pekerja untuk dapat mencapai hasil kerja yang efektif dan efisien. Efektivitas tenaga kerja pada lapangan golf, tidaklah sama pada setiap lapangan golf. Untuk itu artikel ini merekomendasikan guna mencapai keberlanjutan lapangan golf, setiap lapangan golf perlu melakukan kajian efektivitas tenaga kerja.

\section{Ucapan Terima Kasih}

Hasil kajian ini merupakan hasil kerjasama antara Emeralda Golf Club (PT Karabha Digdaya) dengan Program Studi Arsitektur Lanskap, Fakultas Teknik Sipil dan Perencanaan, Institut Sains dan Teknologi Nasional. Untuk itu penulis mengucapkan terima kasih atas bantuan kedua belah pihak yang telah diberikan, baik bantuan moral maupun materil selama proses pelaksanaan studi.

\section{Daftar Pustaka}

Anastasia, N., Yakobus, S., dan Susilawati, C. 2001. Analisa investasi dalam pengambilan keputusan investasi pada pengembangan lapangan golf dan Perumahan Citraraya. Jurnal Manajemen \& Kewirausahaan, 3 (1):14-33.

Arifin, H.S. dan N.H.S. Arifin. 2005. Pemeliharaan taman edisi revisi. Penebar Swadaya, Jakarta.

Beard, J.B. 1982. Turf Management for golf course. Burgess Publishing Company, San Fransisco.

Dewi, E.R. 2014. Evaluasi pemahaman pengetahuan kualitas dan pemeliharaan lapangan golf pada departemen golf operasional Imperial Klub Golf di Lippo Village Tangerang. Jurnal OE, 6 (3):309-326.

Dlukha, S., S. Wardiningsih, Y. Febriani, R.M. Syahadat, dan P.T. Putra. 2017. Pemeliharaan hazard di Padang Golf Matoa Nasional, Jakarta Selatan. Buana Sains, 17 (2):115-124.

Febriani, Y. 1998. Pemeliharaan lanskap common area di Kawasan Wisata Nusa Dua, Bali. Laporan Keterampilan Profesi (Unpublished). Institut Pertanian Bogor.

Guntoro, D., Purwoko, B.S., dan Hurriyah R.G. 2007. Pertumbuhan, serapan hara dan kualitas turfgrass pada beberapa dosis pemberian pupuk hayati mikoriza. Bul. Agron, 35 (2):142-147.

Guntoro, D., Chozin, M.A., Tjahjono, B. dan Mansur, I. 2006. Pemanfaatan cendawan mikoriza arbuskula dan bakteri Azospirillum sp. untuk meningkatkan efisiensi pemupukan pada turfgrass, Bul. Agron. 34 (1): $62-70$.

Hardiman, B. dan Wicaksono, K.P., 2018. Respon 3 jenis turfgrass terhadap interval pemangkasan. Jurnal Produksi Tanaman, 6 (8):1711-1717.

Nasrullah, N. dan Tunggalini, N.K. 2000. Pengaruh pemupukan urea dan nitrogen slow release terhadap pertumbuhan dan kualitas rumput lapangan golf. Bul. Agron. 28 (2):62-65.

Petrick, J.F., S.J. Backman, dan R.D. Bixler. 1999. An investigation of selected factors' impact on golfer satisfaction and perceived value. Journal of Park and Recreation Administration, 17 (1):40-59.

Putra, P.T., R.M. Syahadat, D. Radnawati, S. Nurisjah. 2017. Buku panduan pengelolaan taman Kota Depok. IALI, Jakarta.

Samadikun, B.P. 2007. Dampak pertimbangan ekonomis terhadap tata ruang Kota Jakarta dan Bopunjur. Jurnal PERSIPITASI, 2 (1):34-38.

Utami, A. 2013. Analisis pengendalian persediaan bahan habis pakai chemical dan fertilizer dalam upaya efisiensi biaya pada PT Batamindo Executive Village. Jurnal Akuntansi, Ekonomi, dan Bisnis, 1 (2): 135-139. 